\title{
A Arte Performativa do Passinho Foda: 2008-2018
}

Tatiana Bacal*

Emílio Domingos ${ }^{* *}$

\section{Resumo}

Este artigo tem por objetivo realizar uma etnografia de um vídeo que viralizou e se tornou histórico, o "passinho foda", postado em 2008, por um rapaz de 16 anos, numa lan house do subúrbio carioca localizada no bairro de Pilares. Partindo do conceito de 'arte como mediação' de A. Hennion, de 'arte como agência' de A. Gell e de uma 'antropologia no som' de S. Feld, propomos analisar o caráter inventivo da performance digital do passinho, que inclui criação, produção, dança, postagem, som e imagem.

Palavras-chave: Dança urbana. Som. Imagem. Internet. Performance. Criatividade.

*UFRJ/Professora. E-mail: tatibacal@gmail.com

** E-mail: emiliodomingos@gmail.com 


\title{
The Performative Art of Passinho Foda: 2008-2018
}

\begin{abstract}
This article proposes an ethnography of a short video that went viral in 2008 , posted by a 16 year old boy at a lan house from the suburbs of Rio de Janeiro. We depart with the concept of 'art as mediation' by A. Hennion, of 'art as agency" by A. Gell and of an "anthropology of sound" by S. Feld, our intention is to analyze the inventiveness of the digital performance of passinho, that includes creation, production, dance, posting, sound and images.
\end{abstract}

Keywords: Urban dance. Sound. Image. Internet. Performance. Creativity.

\section{El Arte Performativa D el Passinho Foda: 2008-2018}

\section{Resumen}

Este artículo tiene por objetivo una etnografía de un vídeo que viralizó en 2008, el passinho foda, postado por un joven de 16 años en una lan house del suburbio de Rio de Janeiro, en el barrio de Pilares. A partir del concepto de 'arte como mediación' de A. Hennion, de 'arte como agencia' de A. Gell y de una 'antropología del sonido' de S. Feld, nuestra propuesta es analizar el carácter inventivo de la performance digital del passinho, que incluye creación, producción, danza, postage, sonido y imagen.

Palabras clave: Danza urbana. Sonido. Imagen. Internet. Performance. Creatividad. 
Comecei a me dedicar para aprender mesmo, horas e horas diante do youtube para pegar os passos.

Comentário de uma menina numa página do YouTube

Uma espécie de revelação me veio no hospital. Eu estava doente em Nova York e me perguntava onde tinha visto moças andando como minhas enfermeiras. Eu tinha tempo para refletir sobre isso. Descobri, por fim, que fora no cinema. De volta à França, passei a observar, sobretudo em Paris, a frequência desse andar; as jovens eram francesas e caminhavam também dessa maneira. De fato, os modos de andar americanos, graças ao cinema, começavam a se disseminar entre nós. Marcel Mauss As técnicas do corpo, 1935.

O passinho como modalidade de dança urbana surgiu ao longo da década de 2000, inicialmente nos bailes funk do Rio de Janeiro, e ganhou as redes sociais, como o Orkut ${ }^{1}$, YouTube ${ }^{2}$ e Facebook $^{3}$. 0 passinho mistura diferentes elementos de referências como o break, capoeira, kuduro, contorcionismo, mímica, frevo, performance, combinados à marcação de passos em duas contagens, característico do funk carioca, gênero eletrônico de pista, criado nas periferias e comunidades da cidade nos anos 1980. O passinho, dançado primordialmente por adolescentes e crianças, circula fortemente na internet, e, rapidamente, seus movimentos são colados e recriados em outros contextos locais. 0 passinho já ganhou sua vertente paulista com "O passinho do Romano". Também Belo Horizonte, entre outras cidades brasileiras, recria a sua própria modalidade de dançar o passinho. Ao longo desses anos, alguns dançarinos se profissionalizaram, outros deixaram de dançar, mas a estética e expressividade dessa dança urbana marcam um período específico da história do funk e do Rio de Janeiro.

10 Orkut foi uma das primeiras e mais utilizadas redes sociais no Brasil, criada em 2004, embora tenha sido desabilitada dez anos depois com a ascensão do Facebook.

20 YouTube é uma rede social de compartilhamento de vídeos, criada em 2005, e vendida ao Google no ano seguinte.

3 O Facebook é a maior rede social virtual do mundo, criada em 2004. 
O funk carioca é uma manifestação que surge nas favelas e periferias cariocas na década de 1980, concentrando um grande número de jovens nos bailes, e se estabelece como um novo modelo de negócio e de manifestação artístico-sonora. Desde o surgimento, o gênero foi caracterizado pela mídia tradicional impressa como "música de péssimo gosto", os jovens frequentadores relacionados pejorativamente às facções do crime organizado, os artistas à falta de criatividade, verdadeiro talento e organização de carreiras. Ou seja, o funk vive, desde seu início, a tensão entre ser tão massivo e tornar-se um metagênero de música independente e ao mesmo tempo sofrer forte preconceito midiático, político e cultural por suas qualidades periféricas (Yudice, 1994; Oosterban, 2009; Essinger, 2005; Facina, 2010, 2012). Ao longo de suas quatro décadas, por exemplo, os bailes já foram proibidos pela prefeitura um sem-número de vezes, e o funk só conseguiu se estabelecer como patrimônio cultural brasileiro nos anos $2000^{4}$. Neste artigo propomos uma aproximação ao passinho através do jogo de representações entre os personagens que dançam, que frequentam o universo do passinho, com ênfase em sua forma expressiva, sua arte.

Dessa maneira, o passinho se impõe como manifestação expressiva potente para refletir sobre novas modalidades de perten-

40 passinho segue imbricado na tensão entre discriminação, racismo e violência sofridos por jovens de áreas periféricas do Rio de Janeiro. Se por um lado, Barbosa (2016) chama atenção para o fato do passinho se enquadrar num certo grau do politicamente correto e algo que poderíamos chamar de "assepsia", ao deixar de lado o estigma associado às letras de proibidões, de apologia ao tráfico, ou as consideradas sexistas e pornográficas, por outro lado, a trágica morte de Gambá, considerado rei do passinho, na virada de ano de 2012, por dois seguranças de rua, depois de deixar uma festa de madrugada, evidencia a fragilidade das vidas destes jovens. Outro elemento a ser considerado em outros trabalhos é a coincidência do passinho se dar no período de implementação da política das UPPs (Unidades de Polícia Pacificadora) em algumas favelas cariocas a partir de 2013, aqui também evidenciando a tensão entre uma política altamente racista e discriminatória (a começar pelo nome!), mas que, entre seus efeitos, foi possível a circulação física de jovens em bailes de diferentes comunidades, ampliando possibilidades de encontro, quando antes não era possível em comunidades pertencentes a diferentes facções do tráfico. Esses temas extrapolam os limites deste artigo. 
cimento identitário na segunda década dos 2000. Alia-se aos debates sobre globalização, juventude e novos sentidos de relação entre local e global, centro e periferia, virtual e não-virtual (Marcon, 2013; Marcon e de Noronha, 2018; La Barre, 2010). 0 passinho e outros gêneros e estilos globoperiféricos parecem se encontrar em novos modos de resistência ao criarem modalidades de inventar cultura, sonoridades, danças e modelos de negócio, assim como apontam para um momento de novas subjetividades performadas na internet.

Partindo de um interesse comum direcionado aos modos de criatividade digitais, decidimos lançar mão de uma escrita a quatro mãos em que se acionam etnograficamente o vídeo "passinho foda", postado em 2008, as filmagens que Domingos realizou com alguns personagens do vídeo para seu filme, em 2012, e novamente as filmagens que este realizou para a elaboração de um curta sobre os 10 anos do "passinho foda", em 2018. Nossa metodologia se pautou numa etnografia multissituada (Marcus, 1995) que inclui o ambiente virtual, através da análise do vídeo postado, uma etnografia presencial, através de muitos anos acompanhando os jovens dançarinos de passinho e também através de imagens captadas em vídeo não editadas em 2012 e novamente em 2018. As citações das falas dos personagens que participaram da feitura do vídeo ao longo do artigo baseiam-se principalmente na transcrição integral das filmagens de 2018, realizadas no mês de agosto, quando os rapazes, novamente reunidos no quintal onde foi criado o vídeo de 2008, lembram como foi a eclosão da experiência vivida há dez anos, quando ainda eram adolescentes e protagonizaram a febre do passinho.

Começamos, assim, inspirados em ampliar as noções de 'etnografia do som' e 'etnografia no som', de Steven Feld (2004), para pensar uma 'antropologia na e da imagem', 'uma antropologia na e da dança', 'uma antropologia na e da virtualidade', na relação criativa e analítica com a materialidade e a socialidade da imagem, do som, da dança e do digital. No sentido mais específi- 
co de uma antropologia do som e no som, se Feld se inspira em Rouch para pensar a gravação da imagem e do som como formas de conhecimento, agora nos inspiramos em Feld para levar suas categorias para além do som e pensar os registros - sejam imagéticos, sejam sonoros - como meios de aprendizagem e performance.

A partir dessa proposta teórico-metodológica, objetivamos neste artigo analisar a performance digital do passinho, que inclui a criação, a produção, a dança, a postagem, o som e a imagem, a partir do conceito de arte como mediação de Hennion e de arte como agência de Gell, pois está no processo, na "mecânica", o caráter inventivo desta performatividade. Segundo Mac Dougall (2006), enquadrar contém dois impulsos interconectados - o de enquadrar mas também o de mostrar o que está além ou apesar do enquadramento. "O enquadramento destila e concentra a experiência, é o que impulsiona algum elemento do fundo e nos habilita a aproximá-lo" (MacDougall, 2006, p. 4). Propomos, assim, utilizar a metáfora do enquadramento como propulsora para adentrar o passinho por entre telas, as produzidas por seus produtores e por Domingos em diferentes camadas de tempo.

Em 2013 Emílio Domingos evidenciava um novo fenômeno com o seu filme "A batalha do Passinho" (2013). Exibia uma nova manifestação do funk carioca, uma modalidade de dança urbana que enfatizava novos movimentos no corpo individual e não mais a dança coletiva que integravam os bailes funk e charme até o início dos anos 2000. Os dançarinos passavam a não ser somente jovens e adolescentes, mas também a incluir crianças pequenas, e o próprio fenômeno da dança acabava por modular a sonoridade do funk, diminuindo letras e aumentando as BPMs. Se havia um novo fenômeno cultural sendo criado ao longo da primeira década do segundo milênio na cidade, havia, entre tantos outros temas destacados no filme, a presença protagonista da internet, no sentido de que explodiam vídeos curtos dos dançarinos em ação no YouTube. Os vídeos muitas vezes funciona- 
vam a partir do modelo do duelo, da batalha, cada um postando um movimento de dança em resposta a outro dançarino e com comentários do público que indicavam com curtidas quem havia ganhando a preferência do cada vez mais crescente número de espectadores.

Ao longo do processo de filmagem de "A batalha do passinho", muitos personagens se referiam ao vídeo do "passinho foda" como um grande momento mítico de impacto que derivaria na febre do passinho online e offline. Para seu filme, Domingos filmou três dançarinos que participaram do vídeo em 2012 e, novamente, todos os envolvidos em 2018. É interessante notar que a força viral do vídeo leva Domingos, a partir de sua importância revelada por personagens que entrevistava, a produzir imagens posteriores no mesmo quintal onde se filmou o "passinho foda" e, mais adiante, a pensar em sua importância ao longo de dez anos.

Nesse sentido, o vídeo "passinho foda" está num centro concêntrico de relações, como afirma Gell (1998). A noção de "pessoa distribuída" de Gell propõe uma "teoria da pessoa”, estendida às criações artísticas. Os objetos são manifestações de cultura como um fenômeno coletivo, eles são, como as pessoas, seres aculturados" (Gell, 1998, p. 153). Essa noção se visualiza na imagem metafórica da cebola, fractal, pois, a cada camada que se retira da cebola, vamos encontrando uma série de outras camadas, sem nunca atingir um centro. E as camadas que vão saindo, por sua vez, se constituem como partes dessa cebola em relação ao ambiente. Partindo desta perspectiva, trataremos esse vídeo, como quer Gell, no centro de um arsenal concêntrico de relações que se desdobram para fora e para dentro, como "homúnculos" (Gell, 1998, p. 139-140). Isso porque eles atendem, na escala em que são apresentados, a múltiplas outras camadas que abrem as vias para outras escalas.

Em “Pragmática do gosto”, Hennion (2011) propõe levar a sério o 'amador' e o 'gosto' partindo de uma teoria de mediações que 
se apoia em numerosos elementos heterogêneos. Para o autor (2003), as mediações não se limitam a "transmitir a obra", nem seriam "substitutos que dissolvem sua realidade". Os mediadores são a própria arte. "As mediações na arte têm um status pragmático, são a própria arte que revelam" (Hennion, 2003, p. 88). Poderíamos dizer que as mediações que agenciam o vídeo do "passinho foda" vão desde a câmera disponível para fazer a filmagem, o som, que como diz o dançarino Bruno (apelidado Beiçola), "é o que faz dançar", o corpo que sabe ser engajado pelo passinho, o YouTube, a televisão, o baile, entre tantos outros mediadores.

Uma teoria das mediações e da agência nos habilita a criar conexões parciais e não oposições. Se há algo que o passinho tem a ensinar é de uma socialidade digital, acústica, cinética e imagética que parte desta modalidade de dança urbana. E, também, a importância da imagem para a própria invenção do passinho. Nas palavras de Vitinho:

Quando a gente começou, a febre era nos bailes, todos os bailes tinham rodinhas, várias mulheres, todo mundo dançando nos bailes. Depois que foi pra televisão, a febre da roda, do duelo parou e o passinho passa a ser uma dança mesmo. E a rapaziada que continua, já começa a ter grupo de dança, chamados de bonde. A gente não tinha bonde, a gente gostava de dançar, cada um do seu jeito, ia pra casa do amigo e ficava ensaiando o dia inteiro e depois fazia os vídeos.

Acompanhando a multiplicidade do vídeo, fazendo dela nosso mote, nosso norte, começamos então com uma descrição do vídeo e seguimos com suas películas, camadas, algumas internas e outras externas, sem pretensão de esgotá-las e potencializando suas aberturas epistemológicas. 


\section{V iralizou}

Em 6 de setembro de 2008, durante uma festinha/churrasco de aniversário de 16 anos de Rodrigo (apelido Bitala), num quintal de uma casa típica de subúrbio carioca localizada no bairro de Pilares, ${ }^{5}$ próximo à linha do trem, Rodolfo pegou uma máquina digital portátil, botou pilha nos amigos, os filmou dançando, voltou para casa, editou um trecho. No dia seguinte jogou o vídeo de 1 minuto e 54 segundos no YouTube, com o título "passinho foda".

Alguns dias depois, em 13 de setembro, os amigos filmados começaram a receber mensagens de $\mathrm{MSN}^{6}$, dizendo que estavam na TV. 0 vídeo apareceu na TV Record e depois no programa Fantástico, da TV Globo. No site do YouTube constam 4.636.599 visualizações ${ }^{7}$. 0 vídeo viralizou de tal forma que os meninos começaram a receber imediatamente pedidos para serem adicionados ao Orkut, ao limite que se viram obrigados a abrir mais uma segunda e terceira contas para dar conta dos pedidos, que vinham de todos os lados e estados, como São Paulo e Belo Horizonte. As pessoas pediam em amizade e se mostravam ávidos para aprender e, como eles dizem, "chegar perto", indicando o grau de reconhecimento que alcançaram na época. Nos bailes do Salgueiro, Tuití, Jacaré, Árvore Seca e Chatuba, os rapazes do vídeo passaram a ser reconhecidos, sendo chamados para duelar, receberem bebidas de graça e presentes. De repente eram

5 Pilares é um bairro que é cruzado por duas ruas de suma importância para o tráfego da cidade: Avenida Dom Helder Câmara (antiga Suburbana) e pela Linha Amarela. Em relação ao funk, teve um baile bastante importante na história, o CCIP de Pilares.

60 MSN messenger foi um programa de mensagens instantâneas online, na Microsoft, ativo entre 1999 e 2013, habilitando a conversa em tempo real. Integrado ao serviço de e-mail Hotmail, foi um dos programas mais baixados no Brasil por um público jovem.

7 https://www.youtube.com/watch?v=S-gjytnMvZ8, acessado por último em 09/06/2020. Com o único intuito de criar uma referência comparativa, o maior público de cinema no ano de 2008 no Brasil foi de 5.159.238 para o filme "Madagascar 2 - A grande escapada" (wikipédia). Nesse ano entram como critérios para avaliação o número total de bilhetes vendidos e o número de downloads do filme. 0 padrão numérico de visualizações em 2018 é tão maior que não há como estabelecer uma comparação adequada. 
reconhecidos por toda parte e chamados para a televisão. Era o boom ou a "febre" do passinho. Como diz Beiçola, "foi uma explosão. Nos surpreendeu. A gente não sabia lidar... Eu não sabia lidar, mas todos concordam que foi a melhor época".

Dez anos depois da viralização do vídeo, nenhum dos rapazes, que aparecem retratados abaixo em imagens de 2018, seguiu vida de dançarino profissional, tendo marcado o período de suas adolescências ${ }^{8}$. Vitinho, Victor Cesar, tem 26 anos e trabalha como treinador de futebol; Bruno tem 28 anos, atua como representante comercial na empresa de sua mãe, é casado e tem três filhos; Rodolfo é promotor de merchandising, é casado e tem uma filha de 1 ano; e Rodrigo trabalha num lava-jato e atua como auxiliar de músico em uma gravadora perto de casa. Allan atualmente "é crente e trabalha como barbeiro num salão próximo à casa de Bitala", como dizem os amigos. Não pôde estar presente na gravação do encontro dos criadores do "passinho foda".

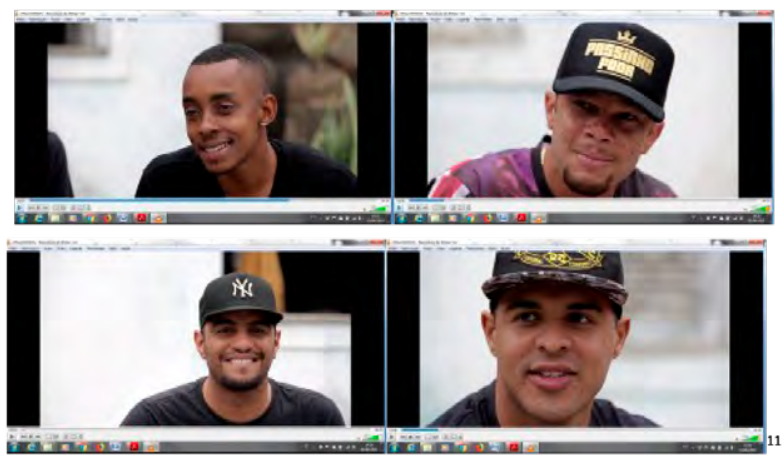

Frames extraídos do filme Dez anos depois, dirigido por Emílio Domingos e produzido pela Osmose Filmes (2020).

8 Um dos principais motivos por deixarem de dançar tem a ver com o fato de considerarem que a música ficou mais acelerada e difícil de acompanhar, seguindo a tendência do jogo contínuo entre velocidade das bpms e dos movimentos das pernas. Mas também apontam critérios muito próprios a um período circunscrito da vida, alegando que hoje sentem "vergonha de dançar" ou "oprimidos por dançarinos melhores" e mais jovens. Ir para o baile ainda é uma prática, mas o modo de habitar este espaço se realiza através de outros modos de estar ali. 
Qual o enquadramento, dispositivo, agência, forma e conteúdo desse vídeo postado em 2008 no YouTube, com diversos comentários saudosos e elogiosos? Poderíamos começar sugerindo que o que se filma é uma dança da qual se entra e se sai da roda, formando duplas temporárias e fazendo que o cenário seja tratado por Rodolfo como um cenário de teatro ou dança, o enquadramento contendo saídas laterais, dianteiras e traseiras. 0 que a câmera persegue e registra é uma dança.

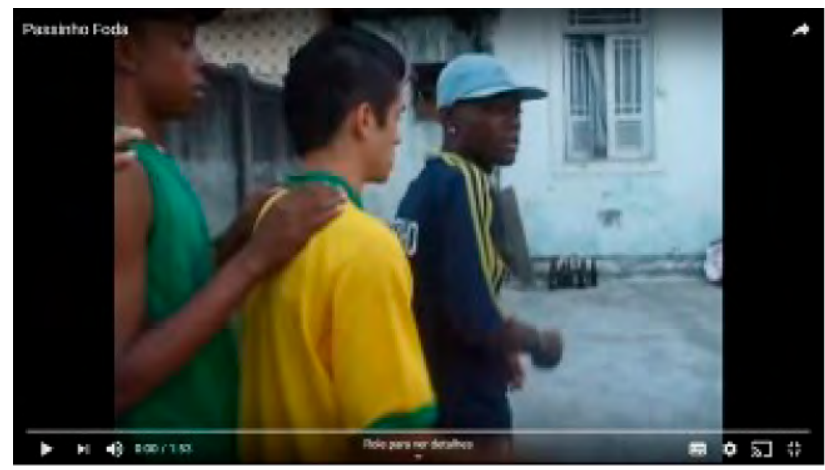

Este printscreen e os próximos foram todos retirados do vídeo Passinho foda https:// www.youtube.com/watch?v=S-gjytnMvZ8, último acesso em 09/06/2020.

O início do vídeo coincide com o início da ideia. Percebe-se uma preparação, uma abertura: três meninos adolescentes de lado, formados em fila, logo seguem de costas, em 'trenzinho', da frente esquerda para o fundo central. 0 cenário é um quintal com uma casa branca e dois janelões. Há vasos grandes de plantas ao longo do muro esquerdo. À medida que chegam num enquadramento mais central, veem-se dois janelões também com vasos de plantas encostados na parede, garrafas de cerveja vazias, duas grandes caixas de som e engradados de cerveja. 

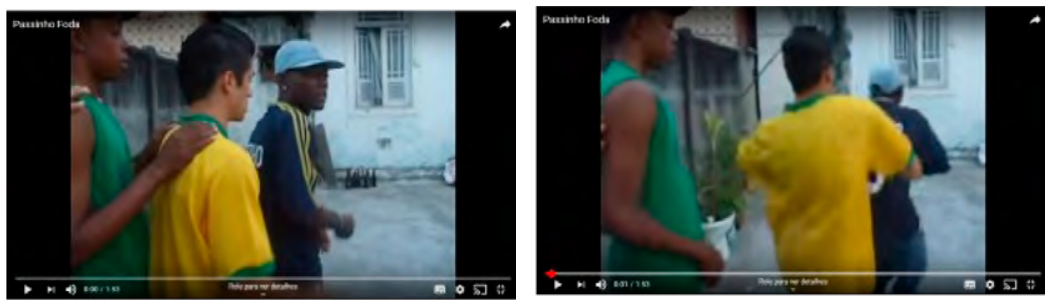

Os três meninos adolescentes vestem camisetas de futebol e bermudões. Allan, o primeiro, usa boné branco, seguido por Marquinhos de camiseta da seleção brasileira amarela, e, por último, Vitinho (Victor Cesar), um rapaz que usa camiseta verde sem mangas. Logo na saída do "bonde"9 , alguém grita perto da câmera: "Vai Rodolfo, tu é um viadinho". Mas Rodolfo, o Rodo, ignora a chamada e continua a filmar.

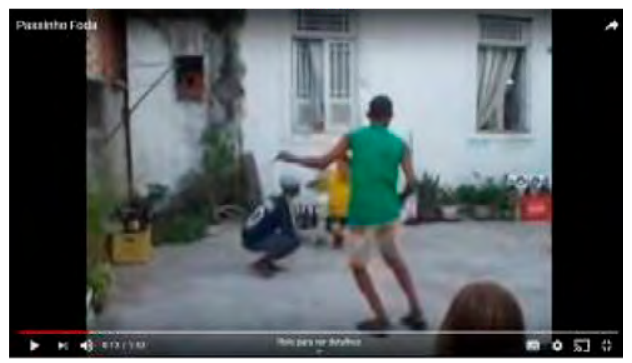

Ele enquadra o rapaz de camiseta verde, o Vitinho, enquanto Marquinhos e Allan dançam juntos, um virado para o outro, alternando a base do passinho com agachamentos e passos de frevo. Vitinho de camiseta verde dança só ao lado direito do par, por trás do par e finalmente realiza sua saída pelo fundo direito por um corredor que provavelmente leva à frente da casa. Sai de cena. $\mathrm{Na}$ entrevista de 2018, Vitinho diz que saiu de cena "na maior", sem perceber que estavam criando algo que teria tanto impacto.

9 Bonde é uma gíria carioca de periferia que designa grupo de amigos, bandas de funk, como bonde do tigrão e grupos de dançarinos. 


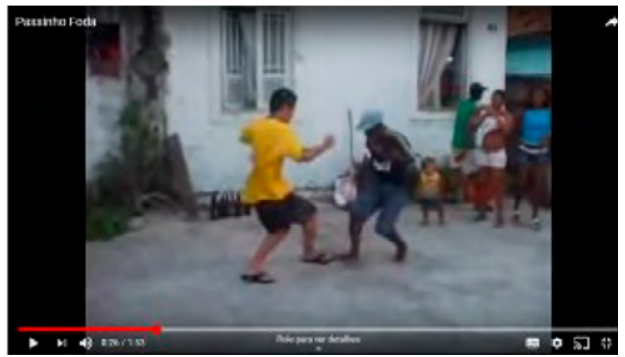

Enquanto Vitinho sai de cena, já estão no enquadramento duas moças e uma menina bem pequena. Uma delas filma os dois rapazes com um celular. E a câmera enquadra a dupla que continua a fazer movimentos rotatórios e agachamentos. Eles dançam ao som da gravação de um mp3 amplificado pelas duas caixas de som. 0 som é do DJ Preto, um remix da música "Antares é o caldeirão".

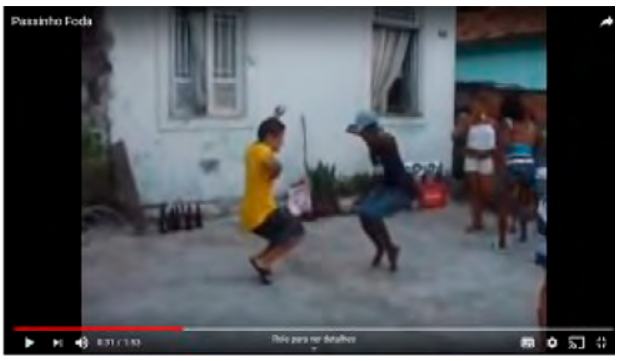

Na frente dos dançarinos, um homem se levanta bloqueando a imagem por alguns instantes e voltamos a ver dupla dançando. Alguém grita: "Vai Beiçola, vai!”. O próprio Marquinhos chama o amigo com a mão e sai pela frente esquerda da cena. Entra Beiçola (Bruno) de costas e cumprimenta Allan com o passo que "imita viado"10, se vira e se posiciona com o corpo bem de frente à câmera.

10 Este passo, denominado "imita viado", se caracteriza por teatralizar trejeitos atribuídos a "homens afeminados". O passinho se caracteriza por uma série de movimentos básicos, "a base", como será visto mais adiante no artigo, mas integra elementos narrativos dentro do tempo que dura a dança. 0 passo "imita viado" integra esta modalidade específica da dança do passinho. 


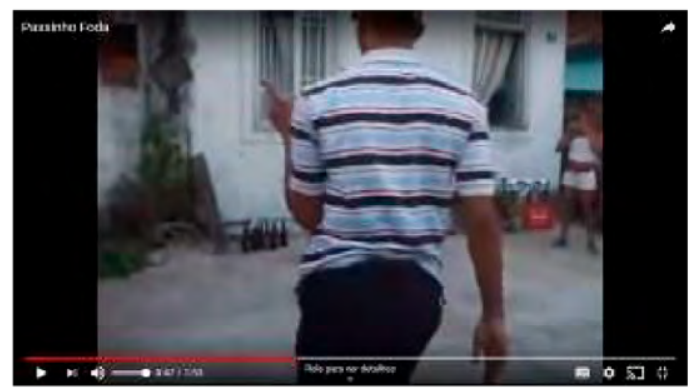

A câmera pela primeira vez enquadra o corpo e depois as pernas e pés. Mas Beiçola logo volta pra trás para se posicionar de frente ao amigo. Os dois dançam durante alguns instantes e Beiçola finaliza saindo também pela frente esquerda do enquadramento.

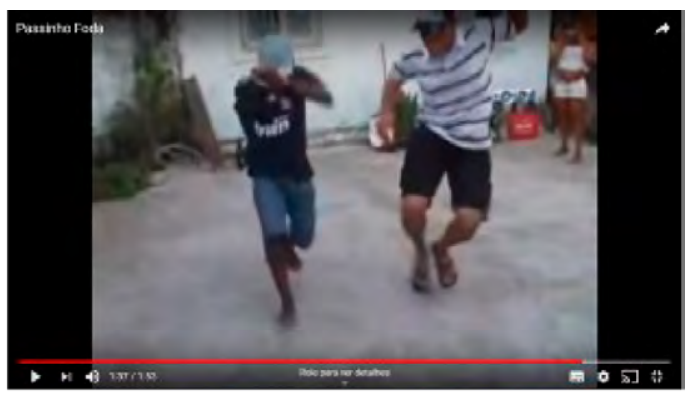

Allan dança sozinho, pega o boné e faz uma wave, movimento típico de break que retira o boné com um movimento de braço.

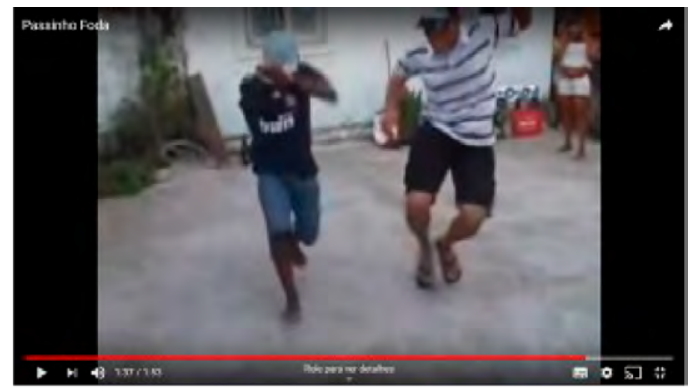


Seguidos de mais alguns movimentos, reconhecemos a camiseta de Beiçola, atravessando a imagem, e o vídeo termina/interrompe. 0 fim parece irromper quando termina a 'brincadeira'.

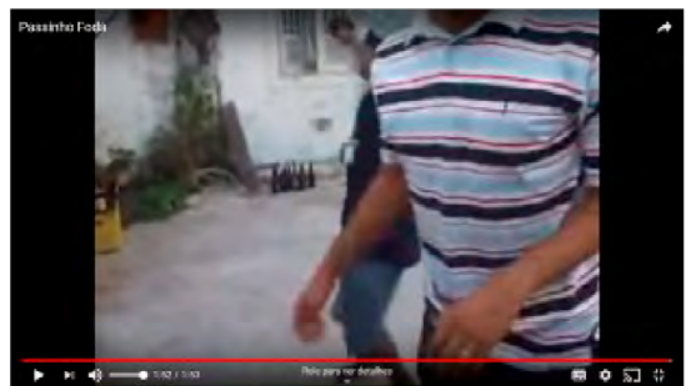

A questão do amador, ou amadorismo, parece ser um elemento que se perpetua no funk, inclusive como estética, como afirma Mizrahi (2010). 0 tosco, a sujeira, o mal-acabado, o arranhado, um som "podrão" e a voz desafinada fazem parte da composição estética. Mais do que ser uma forma de criação que vem de um "ambiente precário" e por isto "nunca se legitimou", sua potência liminar, inacabada, precária é de fato um estilo, uma forma criativa. 0 vídeo, neste sentido, é propositalmente amador e, neste caso, no duplo sentido. Sua inspiração veio de um vídeo que tinham visto antes, de $\mathrm{Abu}$, o primeiro que viram, chamado "passinho do jacaré"11. Segundo eles, foi a inspiração para buscar um nome diferente e chegar ao "passinho foda". Foi amador no sentido de que a intenção foi estabelecer a brincadeira partindo de outro vídeo que viram no YouTube. Não tinham ideia do tamanho impacto que atingiria sua viralização e que atualmente seria considerado uma "relíquia do passinho", como diz um dos posts nos comentários na página do YouTube.

Naquela época Beiçola diz que não existia muito acesso à internet e que o YouTube não era muito conhecido. 0 espaço da lan 
house era muito mais um espaço de estar juntos, de maneira, ao mesmo tempo, online e offline (Vianna, 1997), muito semelhante aos modos de sociabilidade em cybercafés em Trinidad (Miller e Slater, 2004) ${ }^{12}$. Também lembram que Rodolfo tinha uma máquina digital "bem antiga". Com esses depoimentos, os rapazes estão falando de mudanças ocorridas ao longo de dez anos sobre suas relações com as diferentes tecnologias digitais. Um agente importante para a viralização do vídeo com certeza foi sua aparição pelas redes de televisão que passavam os vídeos mais visualizados na internet. Por isso é interessante pensar em uma verdadeira rede através da qual passa o vídeo: YouTube TV - MSN - Orkut - pista de dança. Cada uma das plataformas faz parte dessa rede e se torna uma forma de propulsão e viralização do vídeo para outras.

Ao mesmo tempo, o vídeo segue uma padronização estética, é "amador" enquanto estética, um estilo, como apontado acima: na maneira explicitamente não bem acabada nos modos como Rodolfo corta/edita o filme, no início e no fim deixando um longo plano sequência, com pessoas, sons e os próprios dançarinos que 'invadem' a cena filmada, com uma câmera que demora a pegar os corpos em movimento, por vezes registrando um na frente do outro. Ao cortar um vídeo com menos de dois minutos, o diretor tem incorporado um conhecimento do enquadramento estético, que fora se tornando o padrão do YouTube. Se por um lado não havia um conhecimento prévio de que o vídeo viralizaria, por outro, estavam inscritos no próprio vídeo as características que poderiam fazer-lhe viralizar. Neste sentido, como forma de "zoação" e "brincadeira", a fabricação do vídeo foi uma experiência intencionalmente lúdica e amadora, sem a pretensão do alcance que conquistou, mas em sua estética também es- 
tava a marca do conhecimento estilístico da potência do "tosco", "inacabado", padrão do funk e também de uma certa estética do YouTube.

\section{Som-M ovimento-Som}

Enquanto 'prática performativa' (Sardo, 2017) e realizada por "Concurrencies" ou 'Concomitâncias' (Brydon, Forgren e Fur, 2014), o passinho não aceita uma separação entre dança e som. Beiçola é enfático: "Você só dança o que a música pede". "A música puxa a dança". E ele cita uma música: "se a música pede 'desce, desce até o chão', eu vou pro chão". Essa estreita relação com a música, que engloba a batida e a letra, será determinante para a construção da estética do passinho e para as reflexões das mudanças sofridas pelo estilo ao longo de dez anos, desde o lançamento do vídeo. Bruno deixa claro que as maneiras de dançar em 'sua época' (2008) se diferenciam muito da presente (2018), em função das características do som. Mas Vitinho diz que antes do passinho o grande foco do funk era o proibidão e que já ouviu que o passinho mudou o ritmo do funk por terem "levado para a dança": "A dança tirou o foco no proibidão, de criminalidade, de fazer acontecer". Isso indica uma relação de mútua afetação entre dança e a som. De fato, o funk do passinho é mais rápido, já impactado pelo tamborzão dos anos 2000, é também uma sonoridade com menos letras. Por outro lado, todos os rapazes que agora têm 20 e poucos anos afirmam que não conseguem mais dançar o passinho hoje em dia pela velocidade atual das bpms.

O funk do Rio de Janeiro surgiu produzido na década de 1980 com 127 bpms, configurando o ritmo clássico do Funk Melody. Em 1999, o ritmo foi acelerado, sendo levado para 130 bpms com a eclosão do gênero conhecido como tamborzão, caracterizado pelo uso de samplers de atabaques, inspirados nas músicas do carnaval carioca. Essa mudança influenciou diretamente na integração entre movimentos do corpo e sua temporalidade. Se 
hoje eles alegam estar velhos para a dança, além do critério de idade, é preciso considerar que o ritmo das músicas nos bailes funk sofreu um processo de aceleração. A chegada aos $150 \mathrm{bpms}$ - surgido por volta de 2015 e apelidado de ritmo louco - aos bailes gerou, por consequência, movimentos de dança muito mais rápidos que exigem outras habilidades e produzem um desgaste físico muito maior ${ }^{13}$. Além da passagem do tempo, o fator da velocidade sonora influenciou diretamente na dificuldade de dançar as novas músicas por parte da geração do vídeo de 2008. Por outro lado, e em sentido retroalimentar, foram os dançarinos de passinho que pediam músicas mais rápidas aos DJs, assim também contribuíram para estimular a aceleração das bpms ao longo do tempo.

Uma das características estéticas exploradas por Bacal (2013 e 2016) é que os sons criados digitalmente teriam sido inicialmente considerados "toscos", uma mera cópia dos sons orgânicos, e passam a ser configurados nas sonoridades eletrônicas de pista como padrão estético, junto com as diferentes velocidades das bpms. Neste sentido, segundo Mizrahi (2010), a velocidade, o estilo apropriativo e a falta proposital de cuidado com as colagens configuram o que a autora denomina de estilo ou forma do funk (Mizrahi, 2010). E, neste sentido, o 'estilo favela', segundo a autora, "fornecerá de modo quase ideal, ou ideológico" sua característica distintiva que alia o tamborzão e a sujeira que o acompanha, como, por exemplo, a falta de equalização. Mizrahi afirma que se foi a bpm de 130, presente em algumas variações da eletrônica, como o house, que permitiu ao funk adentrar às playlists cosmopolitas, é exatamente sua "sujeira" que lhe outorga sua diferenciação (Mizrahi, 2010). Por isso velocidade e informalidade são os elementos que, compondo uma estética própria, lhe conferem os sentidos de originalidade e criatividade. 


\section{Corpos-T elas-Corpos}

Seguindo nossa proposta de privilegiar uma perspectiva pautada por mediações e agência, e na pista de abrir as camadas fractais do vídeo, se relacionamos na sessão anterior a estreita relação entre som e movimento, nesta que se inicia pretendemos explorar a relação de aprendizado, também não dual, entre tela e corpo.

Em 1935, em seu artigo seminal sobre "as técnicas do corpo", Mauss chamava atenção para o corpo como primeira ferramenta humana e para os processos de aprendizado, treinamento e habitus corporificados. E ele destaca um elemento fundamental na formação de habitus corporal na década de 1930, o impacto do cinema hollywoodiano na transmissão de um novo habitus do mover, no caminhar das enfermeiras francesas. Agora, em 2018, Vitinho lembra que muita gente apareceu depois da explosão do vídeo, pedindo para aprender o passinho. E o meio de aprendizagem passou a se dar através das imagens na internet. A viralização do vídeo do "passinho foda" não se limitou a receber muitas curtidas e visualizações, houve uma viralização do meio - a criação de apresentação da dança por meios imagéticos. 0 "passinho foda" disseminou uma cultura de se ver o vídeo, postar no YouTube, outro garoto ver o vídeo, estudar os passos do outro, estilizar a própria dança e se filmar. 0 "passinho foda" viralizou também um formato de cultura digital.

Ainda sobre formatos de gravação e aprendizado, no caso da música, Hennion afirma que a grande revolução do jazz não se tratou de um "retorno a um meio oral e tradicional" a romper com o meio escrito de notação. Para o autor, o jazz se estabelece através da escrita de um novo meio: "a escrita da gravação" (Hennion, 2003, p. 91). 0 treinamento, a prática e a performance se estabelecem através da escuta pelos músicos no gramofone e no rádio. Poder escutar a música uma e outra vez e novamente habilitou o trabalho de análise e prática, de tocar nota após nota 
de maneira cada vez mais veloz. 0 autor realiza uma estreita ligação entre a repetição da escuta e a crescente velocidade do ritmo contidas nas improvisações dos jazzistas, intercontectando a escrita da gravação com a velocidade do ritmo. Se é possível falar de modulações do funk ao longo do tempo, estas se dão através das acelerações das bpms, de uma relação que equaciona tempo e velocidade.

Seguindo as formulações de Mauss e Hennion, gostaríamos de ressaltar os processos de aprendizado e imitação corporificada em jogo nos processos de gravação sonora e audiovisual. $\mathrm{Na}$ história do cinema, desde Benjamin (1935), a própria experiência de relação com a tela tem se deslocado desde uma ideia de passividade para uma reação sensorial e corpórea daquele que experimenta o cinema. Neste sentido, David MacDougall afirma que a experiência fílmica envolve um compartilhamento de corporalidade, ou de "impregnação corporal". Segundo MacDougall, "a noção de impregnação sugere uma resposta mais profunda que a empatia, como se o corpo fosse alvejado, ou como se tivesse tomado as qualidades físicas do outro corpo" (MacDougall, 2006, p. 23). Essa sensação de experiência multissensorial também é percebida pelo autor a partir das categorias "colisão, para expressar a experiência de justaposição na montagem" (idem, p. 20) e de "performance e a agência na obra de arte", nos termos de Gell (idem, p. 24).

0 passinho performatiza um habitar materialmente um mundo virtual: um corpo em movimento na tela que combina aprendizado e improvisação, batalha, memória, presente e passado, o offline e o online, o vídeo no YouTube, ainda em 2020, a receber comentários e likes, e visualizações, mantendo vitalidade e possibilidades de agenciamento.

Como afirma MacDougall, interessado no "conhecimento no nascimento do conhecimento", as "imagens corpóreas não são somente imagens de outros corpos; são também as imagens 
de um corpo atrás da câmera e de suas relações com o mundo" (MacDougall, 2006, p. 3). Pensando que em muitos casos dos dançarinos de passinho, o corpo que dança é também o corpo que filma ou um corpo par, um corpo que pode em seguida intercambiar posições, estamos diante da criação de autoimagens. Marquinhos diz lembrar quando Rodolfo mostrou para ele o vídeo de Abu, que dançava e postava vídeos na época. Ele lembra ver o dançarino fazendo um 4, caindo no chão e rodando. Ele diz "ter pirado", "como ele consegue?". E afirma que ficou tentando, tentando fazer os movimentos em casa, até que finalmente saiu e mostrou para o Rodrigo. E aí, combinaram: "maneiro, vamos gravar". Ver na tela, praticar no chão, finalmente conseguir realizar o movimento, filmar e postar são as mediações que possibilitaram criar a performatividade do passinho. Beiçola e Bitala são enfáticos em dizer que o Rodolfo virou "nosso produtor, nosso editor; ele editava os vídeos, juntava a galera para fazer mais outros vídeos. Foram lançados vários vídeos depois".

Rodolfo recorda que quando criou o canal no YouTube "Rodoco 157", foi inicialmente para postar fotos da galera de amigos, os funks que eles curtiam. Foi depois da postagem do "passinho foda” que começou a criar e postar vários vídeos de dança. A questão é que a febre do passinho acontece com a explosão do vídeo. Por exemplo, “De onde sai o passinho foda, o título?”, pergunta Domingos. E Rodolfo responde que o Abu já tinha postado o "passinho do jacaré". Então Rodolfo improvisou e pensou: “0 passinho é foda!". E intitulou seu vídeo. Na hora que é lançado começam a circular vídeos semelhantes intitulados "passinho partido alto", "passinho do frevo", "passinho de..., além disso, cria-se uma página no Orkut mediada pela dançarina Leandra, também intitulada "passinho foda". Do YouTube para a televisão, para os duelos em bailes, para "garotos andando nas ruas treinando movimentos com mãos e cabeça", para as batalhas online e depois offline, "a febre do passinho" englobou estes elementos simultaneamente, uma dança para a câmera em que o registro integra a cena. 
Gonçalves e Head afirmam que a "autorrepresentação consiste, quase por definição, na ausência de uma divisão clara e distinta entre a própria representação e o que ela representa, estabelecendo, assim, uma confusão de horizontes que se manifesta tanto mais fortemente nos casos em que imagens (...) passam a ser matérias centrais destas autorrepresentações". No cenário contemporâneo que envolve a circulação de autorrepresentações, "o personagem criado não é real ou fictício, objetivo ou subjetivo". Para os autores, a autoimagem é por definição uma imagem em transformação, o que acentua o seu devir-imagético (Gonçalves e Head, 2009, p. 20).

\section{A Base}

O curto vídeo que jaz no YouTube nos leva a pensar num fenômeno que em primeiro lugar se pensa através de "concomitâncias", como expressado acima, e é exatamente como "prática performativa" que conduz o presente artigo. Se o som e as telas são fundamentais para adentrar a performatividade deste post, passamos agora para a dança e a categoria-chave para compreendê-la, a "base do passinho". Kaeppler afirma que uma antropologia da dança se traduz como "sistemas estruturados de movimento" (Kaeppler, 1978). Neste sentido, Vitinho afirma que os dançarinos que vieram depois "saíram do nosso padrão". E Domingos pergunta: "qual é o padrão de vocês?". Vitinho ensaia: “Era só o passinho". Beiçola pensa e diz: "Eu não penso em padrão. Passinho foda. O que é o passinho foda?". E a resposta vem com o corpo. Ele se levanta fazendo os quatro movimentos de pés que formam a base do passinho, complementando com a voz: "era só isso mesmo". Além da base, eles afirmam que a inspiração veio de Michael Jackson; de um dançarino francês de hip-hop chamado Salah; e do vídeo do Abu. Vendo um dia um vídeo de meninas dançando frevo, eles adaptaram a dança rápida ao ritmo mais lento do funk e misturaram o frevo com funk. 0 passinho, em última instância, como diz Vitinho: "vai pegando um pouquinho 
daqui e um pouquinho dali; faz o teu e mistura com aquilo ali". Beiçola arremata que "a música também era mais gostosa de dançar, mais lenta. Hoje tá muito mais rápido”.

Enquanto faz a base do passinho com os pés, Beiçola considera que "naquela época eu mais seduzia do que simplesmente mostrava o que eu posso fazer". Na sua fala percebe-se uma sensação de que o passinho foi se tornando mais acrobático e perdendo o 'charme' que prevalecia em 2008, em muitos aspectos se aproximando ao debate apontado por Wesolowski (2012) sobre a profissionalização da capoeira no Brasil do século XXI. A autora verifica nas polêmicas que circundam a institucionalização da profissão da capoeira um deslocamento de ser vivido por seus agentes de uma forma como "livre de jogo", para tornar-se um "esporte".

Para além de uma discussão sobre os caminhos de institucionalização do passinho e sobre a profissionalização de jovens dançarinos, Beiçola incorpora em seus relatos de 2018 a sua própria imagem como mito de origem do passinho. 0 vídeo lançado em 2008 atravessou imagens e imaginários. A vida desses adolescentes que passavam as tardes "brincando" de dançar passa a ser atravessada pelo reconhecimento virtual e nos bailes, na televisão, nas lembranças de outros jovens alegando que a primeira vez que ouviram falar de passinho foi vendo o "passinho foda" no YouTube. Na fala de Beiçola se condensa o discurso da autenticidade de um início mítico ao afirmar que ele gostava da "brincadeira", do "charme", da "gingada". Mas esse truísmo é em seguida contraposto pela afirmação de Vitinho, de que ele gostava "era de duelar". Nessa diferença entre as preferências dos dois percebe-se a estética de uma dança que preza os movimentos singulares de dançarinos individuais.

De qualquer modo, a estética da dança no vídeo "passinho foda" (2008), a interação entre os dançarinos tende à brincadeira, a dançar juntos, em pares, improvisando conjuntamente uma 
cena de dança. Enquanto Beiçola afirma que cada um tinha um estilo e que ele gostava de seduzir, com movimentos mais soltos, Vitinho já frisa que o lance dele era duelar, quebradeira mesmo, alguém vinha com passinho pra cima dele, ele já saía riscando. Rodrigo já amplia a diferença de caracterização dos estilos de dança entre diferentes comunidades. Ele frisa que os dançarinos do Tuiuti, Salgueiro, Penha, Árvore Seca, Jacaré, Chatuba eram muito diferentes deles e lembra que, ao ir ao baile no Salgueiro, "ficava olhando aquela parada, chegava em casa, começava a treinar e quando voltava, a gente já tava igualzinho aos caras". "A gente se juntava, pegava kombi e rodava todos os bailes da cidade: era como um vírus". Essa mesma febre online impulsionava os encontros e duelos de bondes físicos pela cidade.

Em entrevistas realizadas com renomados dançarinos de passinho, Cebolinha e Baianinho, Muniz (2016) afirma que "entre dançarinos é observável uma mistura de carinho e amizade com agressividade e competitividade" (Muniz, 2016, p. 456). Segundo o autor existe uma tensão entre imitação, originalidade e pioneirismo porque terem seus passos copiados pode sim afetar negativamente a performance de um dançarino. Por outro lado, poderíamos acrescentar que as criações de autoimagens filmadas e postadas registram também uma marca própria de expressão corporal por meio da dança, construindo um reconhecimento de originalidade e pioneirismo dos dançarinos. 0 passo filmado é registrado de modo atemporal, existe como prova do seu criador. Mas, ao mesmo tempo, Muniz chama atenção para o fato de Gambá, dançarino assassinado em 2012 e considerado o "Rei do Passinho", ter se destacado mais por seu "carisma em cena" do que especificamente por suas "habilidades técnicas". Assim, Muniz considera que "não podemos definir o passinho partindo apenas da estrutura e da estabilidade de formas, ou seja, determinando quais passos podem ou não ser inseridos no passinho. 0 passinho é comunitária e continuamente construído através da performance da dança e das negociações entre dançarinos" (Muniz, 2016, p. 461). 
As sonoridades funk são criadas através de bases construídas em programas digitais de computadores caseiros sobre as quais se criam os raps. Se levamos essa estética do remix para o corpo, a estética do passinho começa com os quatro movimentos que formam a base do passinho, e que alguns dançarinos também chamam de "sabará". Partindo da "base" e sem nomenclaturas definidas, o passinho se faz com passos "hip-hop" que incluem o wave (o movimento de braços e mãos), a quebra de corpo, o trabalho de pernas de chão, e também o swing (próprios aos bailes de charme ${ }^{14}$ ), a "andadinha" com cruzada de pernas, o "rabiscar" com os pés (que remete aos rabiscos do grafite), agachamentos, o "frevinho", o "imita viado", o "quadradinho" (movimento feito com o dorso), o molejo, o "Michael Jackson", "sacolar" (humilhar na dança cobrindo a cabeça do outro com a camiseta). As apresentações nas batalhas também remetem a uma história que se conta através da comunicação entre os membros do corpo em que podem ser acionados diferentes elementos como acrobacia, performance teatral e velocidade na troca de movimentos.

Podemos sugerir que o passinho tem uma estrutura mínima, que os rapazes consideram sua base. E os elementos que se incorporam a essa base mantêm seu ponto de referência, de reconhecimento, da mesma maneira que as colagens das sonoridades funk não escondem sua procedência, mas as tornam reconhecíveis. 0 que torna interessante uma reflexão sobre o papel da mimesis para o fenômeno do passinho. Segundo Taussig (1993) há na mimesis uma terceira dimensão que reside em sua dupla dimensão entre a cópia e a qualidade visceral do percepto, que une aquele que vê e o que é visualizado (Taussig, 1993, p. 24-25). Ainda no caminho da criatividade mimética, Bhabha (1998) afirma que "o discurso da mímica deve produzir continuamente seu desliza-

14 Os bailes charme são festas onde se dança ao som de R\&B contemporâneo e o new jack swing. Com origem na década de 1970, se populariza na década de 1980 e foi ganhando novas nuances ao longo do tempo. Seus frequentadores usam roupas elegantes e estilo "afro", o charme também é uma dança caracterizada por variados passos criados nos próprios bailes. 
mento, seu excesso, sua diferença que é ela mesma um processo de recusa" (Bhabha,1998, p. 130). Então tudo que "entra para o passinho" se reconhece, se faz visível e se apreende. E é exatamente nesse processo que ganha sua riqueza, mas esta dinâmica deve estar enquadrada em sua estrutura mínima, sua base.

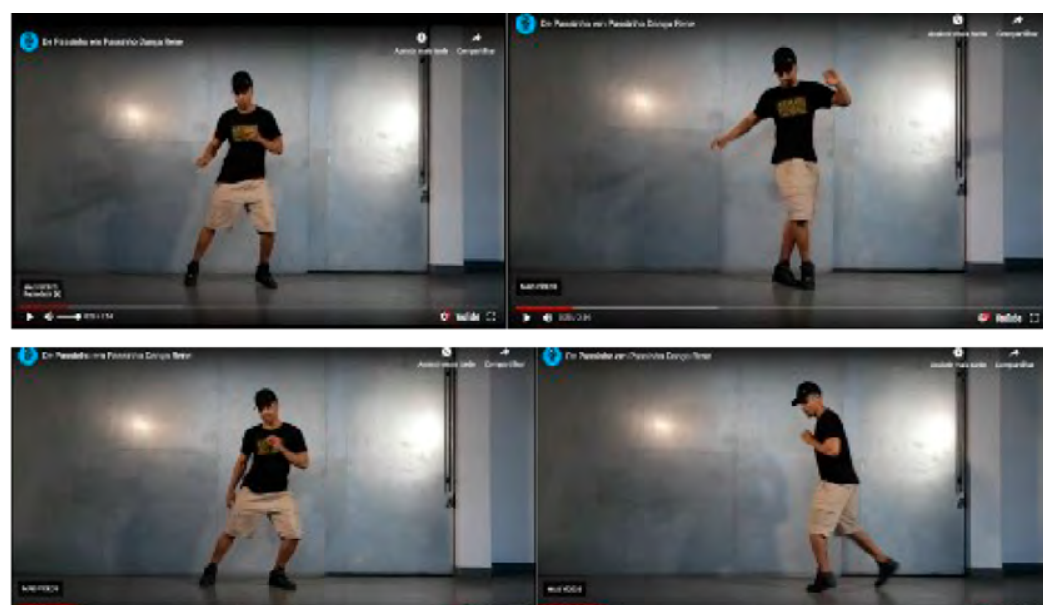

Rene mostra os passos que fazem a base do passinho em gravação para o site criado por Emílio Domingos, “de passinho em passinho" (2018).

Vitinho diz que inicialmente havia a intenção de se diferenciar de outras danças urbanas, como o break: "O nome já diz, o passinho é outra coisa”. Se alguém mandava um break, já perdia, já saía do passinho e nossa galera era só passinho". Rodolfo contemporiza que os elementos iniciais do passinho eram o swing, passinho, break e frevo e o estilo era mais gingado. "Do passinho puxa o break, do passinho puxa o frevo; do passinho não vai e fica no break, já não é funk, vira hip-hop. Você não pode dançar samba e de repente começar a dançar rock", assim sintetizando a relação entre estilo e apropriação próprias à dança do passinho. Para finalizar, eles afirmam que a "manha da dança" está em combinar o molejo do movimento de pés sem ficar desengonçado na parte de cima do corpo. 0 referencial da música, "o que 
pede", a base, a improvisação, o tempo de dança e a harmonia da totalidade do corpo são os elementos estéticos que conformam a qualidade da dança.

A mimese de passos de outras danças só é admitida como brigolagem para o passinho. Como referência de memória corporal e de provocação sobre a criatividade e o desafio para habilidade dos que incorporam os passos ao ritmo, mas também as possibilidades da habilidade corporal. Parece que a aceitação passa pela tradução e pela liminaridade com que os passos de outras danças dialogam com os ritmos e com a continuidade de um passo para o outro. Neste sentido uma das características do fenômeno estaria nessa liminaridade e na transição de passos harmonizados pela sonoridade. Inspirado em Paul Carter e seu conceito de "política do chão" - que se conformaria "por um atentar agudo às particularidades físicas de todos os elementos de uma situação, sabendo que essas particularidades se coformatam num plano de composição entre corpo e chão chamado história" - o estudioso da dança André Lepecki afirma que

uma política coreográfica do chão atentaria à maneira como coreografias determinam os modos como danças fincam seus pés nos chãos que as sustentam; e como diferentes chãos sustentam diferentes danças transformando-as, mas também se transformando no processo. Nessa dialética infinita, uma corresonância coconstitutiva se estabelece entre danças e seus lugares; e entre lugares e suas danças (Lepecki, 2012, p. 43).

\section{Considerações Finais}

Para finalizar, gostaríamos apenas de frisar duas propostas desenvolvidas no texto. A primeira remete à ideia de que o passinho por entre telas parece indicar uma abordagem teórico-medotodológica performativa que privilegia as mediações e a agência como modalidades para acionar uma sociologia e antropologia 
da arte. Neste aspecto, imagem, internet, dança, som, viralização são elementos a não serem pensados enquanto domínios separados, mas enquanto dimensões sempre relacionais.

A segunda proposta diz respeito ao fato de que, como afirma Appadurai (1997), o contexto contemporâneo envolve interações de uma nova ordem e intensidade a partir da explosão tecnológica nos domínios da informação e do transporte. Este contexto contemporâneo marcaria especificamente o modo atual dos "fluxos globais" (que sempre existiram) através do aumento em velocidade, escala e volume destes fluxos. Neste cenário, a arte do passinho como um exemplo das manifestações expressivas da globoperiferia é privilegiada para pensar os "processos de hibridação" do mundo contemporâneo que exigem novas teorias para interpretar a transformação do mundo e da própria arte. Assim, Steven Feld (1995) chama atenção para o fato da música popular ser central neste momento "rizômico", por estar iconicamente "relacionada a uma produção cultural mais ampla de identidade local, e ligada a contextos e ocasiões de participação comunitária". Segundo Feld, esta é uma perfeita arena para se entender as atuais dinâmicas entre "raízes e desenraizamento" e entre "homogeneização e heterogeneização" (Feld, 1995, p. 107). Neste sentido, poderíamos acrescentar, é que o passinho e o funk são globoperiféricos, já que reconfiguram as relações entre centro e periferia, como afirma Vianna, num mundo em que o centro cada vez mais se aproxima da "periferia da periferia" (Vianna, 2006). As sonoridades e danças da globoperiferia dinamizam intensidade e velocidade, tensionando ideais de heterogeneidade e homogeneidade culturais, mistura e diferenciação num momento em que os híbridos estão mais evidentes (Latour, 1994).

A modo de um pensamento final, gostaríamos de dizer que filmar, produzir uma base, criar um rap, dançar, postar, circular, montar o baile são formatos novos de autoria que configuram resistências subjetivas. Neste processo, modificam seus corpos, seus pensamentos, seus desejos, sua percepção, como afirma 
Blacking (2007), e não se limitam a pura reflexão. A arte do passinho e as sonoridades e danças da globoperiferia ao inventarem cultura se configuram como um meio pelo qual a estrutura social é criada.

\section{Ref erências}

Appadurai, Arjun. Modernity at Large: cultural dimensions of Globalization. University of Minnesota Press. 1997.

Asante, M.K. Afrocentricity. Trenton, NJ: Africa World Press. 1988.

Bacal, Tatiana. 0 produtor como autor: o digital como ferramenta, fetiche e estética. Rio de Janeiro, /7Letras, 2016.

. Música, máquinas e humanos: os djs no cenário da música eletrônica. Rio de Janeiro: Apicuri, 2012.

e Naves, Santuza Cambraia. Inventando tecnologias e produzindo sons: relações estabelecidas entre produtores sonoros e tecnologias de criação. In. Simone SÁ, Rumos da cultura da música. Negócios, estéticas, linguagens e audibilidades. Rio de Janeiro: Ed. Sulina e Globo Universidade, 2010.

Bhabha, Homi K. O local da cultura. Belo Horizonte: Ed. UFMG, 1998

Blacking, John. Música, cultura e experiência. Cadernos de Campo, v. 16, pp. 201-218. 2007.

Benjamin, Walter. Magia e técnica, arte e política: ensaios sobre literatura e história da cultura. Obras escolhidas Vol. 1. Editora brasiliense, São Paulo. 1986.

Brydon, Diana, Forsgren, Peter ans Fyr, Gonlüg. (editors). Concurrent Imaginaries, Postcolonial worlds. Toward Revised Histories. 2017.

Essinger, Silvio. Batidão: uma história do funk. Rio de Janeiro: Record, 2005.

Facina, Adriana e Carvalho Lopes, Adriana. Cidade do Funk: expressões da diáspora negra nas favelas cariocas. Revista Geral da Cidade do Rio de Janeiro. N.6, 2012, p.193 - 206.

Facina, Adriana. "Eu só quero é ser feliz": quem é a juventude funkeira no Rio de Janeiro. Revista Epos, 2010. 
Feld, Steven. From Schizophonia to Schismogenesis: the discourses and Practices of World Music and World Beat. In. G. Marcus \&amp; F. Meyers. The Traffic in Culture: refiguring Art and Anthropology. University of California Press. Berkely and Los Angeles, California, 1995.

Gonçalves, Marco Antonio e Head, Scott. Confabulações da alteridade: imagens dos outros (e) de si mesmos. In Devires imagéticos: a etnografia, o outro e suas imagens. Marco Antonio Gonçalves e Scott Head (orgs.). Rio de Janeiro, Faperj e 7Letras, 2009.

Hennion, Antoine. Music and Mediation. Toward a New Sociology of Music In. The Cultural Study of Music - a critical introduction. Martin Clayton, Trevor Herbert, Richard Middleton (eds.) New York and London. 2003.

. Pragmática do Gosto. Desigualdade \& Diversidade - Revista de Ciências Sociais da PUC-Rio, no 8, jan/jul pp. 253-277. 2011.

Herschmann, Micael. 0 funk e o hip-hop invadem a cena. Rio de Janeiro: Ed. UFRJ. 2005.

Herschmann, Micael (org). Abalando os anos 90: funk e hip hop: globalizaçãoo, violência e estilo cultural. Rio de Janeiro: Rocco, 1997

Kaeppler, Adrienne L. Dance in Anthropological perspective. Annual Review of Anthropology. 1978.

Kent, Lauren, Breaking Grahamstown; Breakin' the Dance: Exploring the Role of Break Dancing in the Construction of a Break Dancer's Identity. Journal of Hip Hop Studies, Vol. 1, Issue 2. Cape Town, 2014.

La Barre, Jorge de. Música, cidade, etnicidade: explorando cenas musicais em Lisboa, in CÔRTE-REAL, Maria de São José (org.), Revista Migrações - Número Temático Música e Migração, Outubro 2010, n. ํ 7, Lisboa: ACIDI, 2010.

Lepecki, André. Coreopolítica e coreopolícia. ILHA, v.13, n.1, jan/jun (2011) 2012.

MacDougall. The corporeal image: film, ethnography, and the senses. Princeton University Press, New Jersey, 2006.

Marcon, Frank e de Noronha, Danielle Parfentieff (orgs.). Juventudes e movimentos. Aracaju, Criação, 2018.

Marcon, Frank. O kuduro como expressão da juventude em Portugal: estilos de vida e processos de identificação. Soc. estado. vol.28 no.1 Brasília Jan./ Apr. 2013.

. O kuduro, práticas e resignificações da música: cultura e política entre Angola, Brasil e Portugal. História Revista. V.18, n.2. 2013. 
Marcus, George E. Ethnography in/of the world system: the emergence of multi-sited ethnography. Annual Review of Anthropology, Palo Alto, California, v. 24, pp. 95-117, 1995.

Miller, D. e Slater, D. (2004). Etnografia on e off-line: cybercafés em Trinidad. Horizontes Antropológicos, ano 10, n. 21.

Mizrahi, Mylene. 'É o beat que dita': criatividade e a não-proeminência da palavra na estética Funk Carioca. In. Desigualdade \& Diversidade: Revista de Ciências Sociais da PUC-Rio n. 7, julho/dezembro 2010.

Muniz, Bruno Barboza. Quem precisa de cultura? 0 capital existencial do funk e a conveniência da cultura. Sociologia e Antropologia, 2016, vol.6, n.2, pp.447-467.

Oosterbaan, Martijn. Sonic Supremacy: Sound, Space and Charisma in a Favela in Rio de Janeiro. Critique of Anthropology, Vol. 29, No. 1 (Mar.). 2009.

Sardo, Susana. Ethnomusicology and its sisyphus. Inter-knowledge, dialogue and prudence for a disciplinary (re) classification. World Music Studies, 2016.

Michael. Mimesis and Alterity: a particular history of the senses. New York and London. Routledge, 1993

Vianna, Hermano. 0 mundo funk carioca. Jorge Zahar editor. Rio de Janeiro. 1988.

Vianna, Hermano (org.). Galeras Cariocas: territórios de conflitos e encontros culturais. Editora UFRJ, Rio de Janeiro. 1997

Vianna, H. “Central da periferia”. 2006

Wesolowski, Katya. Professionalizing Capoeira: the politics of play in twentyfirst-century Brazil. In. Latin American Perspectives, 2012.

Yudice, George. 1994. The Funkification of Rio. In: Rose, Tricia. Microphone Fiends: Youth Music and Youth Culture. New York; London: Routledge.

Recebido em 16/03/2020

Aprovado em 17/06/2020 
